\title{
The Integrated Role of Personal Values and Theory of Planned Behavior to Form a Sustainable Entrepreneurial Intention
}

\author{
Nosheena Yasir ${ }^{1, *(\mathbb{D})}$, Nasir Mahmood ${ }^{2}\left(\mathbb{D}\right.$, Hafiz Shakir Mehmood ${ }^{3}$, Osama Rashid $^{4}$ and An Liren ${ }^{1}$ \\ 1 School of Economics and Management, Northwest University, Xi'an 710127, China; anlr@tom.com \\ 2 School of Management Sciences, Northwestern Polytechnical University, Xi'an 710072, China; \\ nasirmahmood@nwpu.edu.cn \\ 3 School of Information and Technology, Northwest University, Xi'an 710127, China; shakir004@hotmail.com \\ 4 Department of Civil Engineering, University of Engineering and Technology, Lahore 54890, Pakistan; \\ osamarashid96@hotmail.com \\ * Correspondence: nosheena.yaqoob@yahoo.com
}

Citation: Yasir, N.; Mahmood, N.; Mehmood, H.S.; Rashid, O.; Liren, A. The Integrated Role of Personal

Values and Theory of Planned Behavior to Form a Sustainable Entrepreneurial Intention.

Sustainability 2021, 13, 9249

https://doi.org/10.3390/su13169249

Academic Editors: Andrea Pérez and Igor Alvarez-Etxeberria

Received: 12 July 2021

Accepted: 13 August 2021

Published: 18 August 2021

Publisher's Note: MDPI stays neutral with regard to jurisdictional claims in published maps and institutional affiliations.

Copyright: (c) 2021 by the authors. Licensee MDPI, Basel, Switzerland. This article is an open access article distributed under the terms and conditions of the Creative Commons Attribution (CC BY) license (https:/ / creativecommons.org/licenses/by/ $4.0 /)$

\begin{abstract}
Intentions have been described as a key driver of sustainable entrepreneurial opportunity recognition and eventually activity. As a result of this study, interest may increase in entrepreneurship intentions across numerous entrepreneurial levels and styles, specifically from the point of view of sustainability. However, research to date has not been able to completely determine how the intrinsic complications of instantaneously producing social, environmental, and economic means will have an impact on the intentions of university students. This study sought to inspect the impact of self-transcending and self-enhancing value on the advent of intentions. The theory of planned behavior is an adaptive theory that this study quantitatively analyzed using a structural equation model and survey data from 577 university students in Punjab, Pakistan. The empirical findings show that altruistic, biospheric, hedonic, and egoistic values all have an indirect effect on sustainability-driven entrepreneurial intentions, which is important to understand when assessing attitudes toward sustainable entrepreneurship and perceived behavior control. In essence, attitudes, perceived behavior, and social norms all affect aspirations to become a sustainable entrepreneur. In real-world terms, the findings indicate that by using value activation techniques to increase attitudes and educational interest, practitioners may promote sustainable entrepreneurial intentions. It is also suggested how government services could be improved as part of the strategy.
\end{abstract}

Keywords: self-transcending and self-enhancing values; attitude towards sustainable entrepreneurship; sustainable entrepreneurial intention; triple bottom line; opportunity recognition

\section{Introduction}

Sustainable entrepreneurship involves "transforming a region into a state that is more financially and socially sustainable through the discovery along with the use of economic opportunities through the emergence of market imbalances", [1]. As a result of wasteful actions, environmental issues, such as waste, global warming, loss of natural habitats, ozone depletion, deforestation, and desertification, have arisen [2,3]. Furthermore, rapid economic development, the overuse of natural resources, and wasteful consumption have all wreaked havoc on the climate, drawing international attention [4]. As a result, sustainable development has been cited as a force guiding sustainable entrepreneurs $[5,6]$. This is because sustainable entrepreneurs aim to strike a balance between communal, environmental, and monetary objectives [7-9]. In this respect, compared to conglomerates, sustainable entrepreneurs play a key role in progress and in the transition to a circular economy [10], the integration of external dynamic skills [11], and green human resource management [12]. As a result, the model of enforcing multiple policies to meet current needs without jeopardizing the opportunities of future generations has become a core concern of academic and scientific discussion [13]. As a result, academia has become interested in the basic 
motivations and intentions behind becoming an entrepreneur. Entrepreneurial purpose in particular is vital to comprehending entrepreneurship as it explains why people choose to create or own a corporation [14]. Despite this growing curiosity, there is still a scarcity of information on entrepreneurial intentions in different contexts.

In terms of value generation, sustainable and social entrepreneurship is different from conventional entrepreneurship. Entrepreneurs were once believed to be mainly concerned with generating economic profit. Economic value development, on the other hand, has been seen as a way to combine various principles for a more modern type of entrepreneurship [7,15-18]. Although environmental and social are two separate types of entrepreneurship, they each offer essential expertise in running a sustainable enterprise. However, by integrating the development of social, environmental, and economic value, this emerging entrepreneurship field has the power to ensure society's future well-being [19]. Similarly, Patzelt and Shepherd [9] predict that sustainable entrepreneurship could play a significant role in sustaining the environment and providing lucrative (both monetary and otherwise) benefits for entrepreneurs, shareholders, and communities. Despite this significance, the Global Entrepreneurship Monitor estimates that the total numbers of adults working in companies $(3.6 \%)$ and developments $(3.7 \%)$ with aims other than financial benefit are relatively low. An earlier study from 2009 [20] suggests that these proportions have remained largely constant. One reason for the present low level of participation could be the perceived personal benefit of successfully pursuing sustainable intentions [19]. These personal principles will affect a person's decision regarding whether or not to partake in sustainable entrepreneurship and are generally recognized as the most illustrative and objective indicator of entrepreneurial conduct $[14,21]$. To this end, a legitimate and important debate arises among university graduates about the fundamental values of self-enhancement and self-transcendence in the context of sustainable entrepreneurship. These issues can influence an entrepreneur's intention to initiate sustainable entrepreneurship, even though intention is generally considered to be the most important and neutral predictor of sustainable entrepreneurial behavior [21]. Unfortunately, awareness of the effect of these problems on the individual's intention to become a sustainable entrepreneur is currently minimal.

According to recent studies, the initial step in this direction is to follow an established framework of sustainable entrepreneurial-specific interventions, along with merit sustainability-centered decision-making [21]. Hence, the existing research concentrates on the effect of self-transcending and self-enhancing principles on aim development in sustainable entrepreneurship. This is especially significant due to the fact that sustainable entrepreneurship is a "value-encumbered" philosophy, and sustainable entrepreneurs use precise values as guiding principles, which distinguishes it from conventional entrepreneurship [9,22]. Sustainable entrepreneurship ultimately seeks to not only combine the production of cultural, fiscal, and environmental meaning, but also to sustain these values over time [1]. Economic value formation, on the other hand, has traditionally been a crucial part of traditional entrepreneurship, wherein entrepreneurs take different steps to either pursue or enhance different areas of monetary value [23]. Environmental entrepreneurship focuses on environmental value creation, while social entrepreneurship is closely linked to community, and relates to many forms of social value creation [24]. While the previous study concentrated solely on job principles and general altruism in its attempt to understand the necessity of sustainable entrepreneurship, these aspects are no longer the most important [21]. Hence, the current study proposes a model of sustainable entrepreneurial intention that involves self-transcending and self-enhancing (i.e., altruistic, biospheric, selfish, and hedonistic) values. These two forms of belief discriminate between altruism towards other citizens (social altruism) and altruism towards the environment (i.e., biosphere altruism) [25]. In addition, type-specific entrepreneurial activities, and self-transcendence and self-enhancing values, especially in developing countries, have not been investigated [23]. The goal of this study is to integrate these intuitions into the theory of planned behavior (TPB) in order to understand how sustainable entrepreneurship intentions are created [26]. Specifically, this study does this by incorporating concepts 
of self-transcendence and self-enhancement in the distinction between types of altruism within the theory of planned behavior (TPB). Therefore, we also place greater emphasis on the behavioral factors in decision-making in the context of organization sustainability practices [27]. As a result, this study helps to precisely conceptualize the personal values associated with the formation of intentions for sustainable entrepreneurship. This study focuses specifically on the impact of self-transcendence and self-enhancement on sustainable entrepreneurial intentions via their effect on character in this specific context.

The analysis then describes the theoretical context, the data collection approach, and the analytical method. The findings are then discussed, accompanied by debates, assumptions, policy consequences, and insights. Finally, the study's shortcomings are identified in the context of future potential work.

\section{Literature Review and Hypotheses Development}

Recognizing opportunities is the first step in entrepreneurship and sustainable entrepreneurship $[28,29]$. Entrepreneurship is generally understood as a consciously planned behavior. Clark [30] defined intention as the specific tendency of an individual to carry out a single act or a sequence of acts. Hence, the goal is "directed towards comprehending the behavior in which an individual participates" [31]. As a result, when starting a business, entrepreneurs do not simply respond to external stimulation or catalysis, but rather adopt a carefully organized process [14]. The planned behavior theory (TPB) is among the most widely used and well-tested theories for predicting entrepreneurial intentions [14,32,33]. As a result, some studies have used planned behavior theory to explain the formation of unconventional entrepreneurial intentions, such as social [34] and sustainable [24] entrepreneurship. As such, the present research only uses the pre-behavioral component of the TPB, which is widely used and validated in the entrepreneurial tradition $[21,35]$. Attitudes toward sustainability, subjective norms, and perceived behavioral management in particular influence intentions. The first two relate to whether a certain action is beneficial, while the third helps assess the behavior's viability. Each of the three variables is dependent on a person's confidence in the advantages of a given action [26]. Therefore, the current research includes the antecedents of TPB, as follows:

- Attitude toward sustainability, which, when perceiving the positive or negative outcome of a behavior, is a fundamental determinant of sustainability practice [36];

- $\quad$ TPB refers to the presumptions of a person as to whether most people would reject or accept a particular action [26]. It thus concerns how to resist or adhere to the social atmosphere in order to become a sustainable entrepreneur [21]

- Compared to the two other antecedents, perceived behavioral control offers superior perceived self-efficacy and perceived controllability [37]. This model is a combination of performing a particular behavior and confidence in one's abilities, as well as future facilitators and obstacles.

\subsection{The Role of Personal Value and Sustainable Intention}

Values have an impact on how people assess different facets of a situation, and what solutions are perceived [38]. Similarly, when considering personal values for the production of sustainable intention, two dimensions can be delineated, based on Schwartz's [39] value theory. (1) This theory indicates that self-transcendence values impact environmentally associated beliefs, attitudes, possibilities, and behaviors, and its effects on biological values may be exclusive [40,41]. (2) People with self-enhancement values, on the other hand, make decisions based on risks and rewards-when the potential individual gains of those acts outweigh the perceived costs, people with high self-improvement beliefs behave proenvironmentally. Individual context concerns are purely unbiased variables, and their effects on plans to become a sustainable entrepreneur are mediated via other variables in the model [26,42]. We contend that since they are trait-specific within an organism, all significant effects of self-transcending and self-enhancing beliefs on an individual's actions 
can be described as individual context variables [39]. This rationale will be addressed further below, and the study's hypotheses will be then outlined.

\subsection{Theoretical Framework of the Theory of Planned Behavior for Developing Sustainable Intention}

Sustainability orientation has been identified as a factor influencing sustainable entrepreneurial action, and as an antecedent of sustainable entrepreneurial intention, in the literature on sustainable development $[1,6,8]$. In the theory of planned behavior (TPB), attitudes represent an individual's preference for a specific action. Positive views of being a sustainable entrepreneur have been shown to have a large effect on intention to become one [21]. Individuals who have a more optimistic view of sustainable actions are more likely to act on their beliefs [43]. In the same sense, employees with more pro-environmental views are much more likely to pursue sustainable business models [44]. As an end result, it may be much more effective to domesticate sustainable entrepreneurial intentions; for this reason, we rely on humans having more positive attitudes towards sustainable entrepreneurship.

Hypothesis 1a (H1a). A positive attitude towards sustainable entrepreneurship positively influences sustainability intention.

The effect of the social environment on human behavior is expressed via subjective norms. Surprisingly, subjective standards have the least impact on typical entrepreneurial intentions [32]. However, potential societal pressure to adopt certain principles plays a crucial role in the adoption of renewable technology [45]. Furthermore, Ref. [46] demonstrates that perceived social encouragement will lead to sustainable entrepreneurial development. As a consequence, we consider that when human beings are exposed to the normalization of sustainable entrepreneurship, they are much more likely to pursue sustainable intentions.

Hypothesis $\mathbf{1 b}$ (H1b). A positive subjective normalized view of the social climate has a positive effect on sustainable intentions.

According to a meta-analysis [47], while perceived behavioral control is a combination of two concepts, "controllability items only forecast intentions when paired with self-efficacy items, and self-efficacy tests allowed for increased variation in both intentions and behaviors" [48]. As such, traditional entrepreneurship literature has identified a strong correlation between perceived behavioral effects and entrepreneurial intentions [14,32]. This is crucial, because socially demanding situations concerning sustainable development are often viewed as impossible to resolve; some academics have described them as "wicked problems" [49,50].

Hypothesis 1c (H1c). Becoming a sustainable entrepreneur has a positive impact on sustainable intentions by way of high perceived behavioral control.

\subsection{The Role of Self-Transcending Values, Attitudes towards Sustainable Entrepreneurship, and Perceived Behavior Control}

The first dimension of "values theory" is self-transcendence [39]. This separates values of openness to exchange from conservatism and indicates whether or not human beings are receptive to new things and ideas. Since sustainable entrepreneurs seek sustainable improvement through business ventures [51], they are both seasoned-social and pro-environmental when determining their actions, as their motive is to encourage changes in value, such as self-enhancement (financial) and self-transcendence (social and environmental) $[8,9]$. The former is usually developed within an enterprise, whilst the latter is recorded at the social level [24]. Altruism is defined as "individual drive to promote the wellbeing of others" [52] and has thus been identified as one of the key bases for the desire to establish a sustainable business [9]. Individuals may be acting altruistically because of (sub)conscious self-interest, a large body of research suggests $[9,53]$. They may hope 
for reciprocation, a positive reputation, or a reduction in personal pain derived from the other's circumstances, as a result of their altruistic act [54,55]. However, when others benefit through business entrepreneurship, studies of social entrepreneurship have shown that individuals choose empathy-based altruism ("Help and subject in empathy with others" [54]). This suggests that their primary altruistic drive is to help others in need, rather than to pursue their own goals [52]. Such an altruistic desire to start a social entrepreneurship demands both perspective-taking and sympathetic care, in order to effectively relate to the recipients' position [56,57]. We should also anticipate a sort of biospheric altruism from sustainable entrepreneurs, which is a concern for the health of not only different human beings, but also different organisms [9]. However, in the social entrepreneurship and sustainable literature, such biospheric altruism has yet to be experimentally examined in the context of intention creation $[9,19]$.

Choices, beliefs, attitudes, and actions have been linked to both pro-social and proenvironmental values [58]. People with strong biospheric and altruistic values may find these to be applicable and important when negotiating the numerous demanding situations that could occur when sustainability and economic fulfillment are both pursued, given that they experience sustainability as a proper objective based on their ideals [9]. At the same time, their stronger intellectual ability to employ thoughtful perception and to experience empathetic apprehension may make them more equipped to meet these aims [56]. Furthermore, if the possibility of working as a sustainable entrepreneur adheres to an individual's personal beliefs, it may create a sense of significance and empowerment [59]. As previously stated, perceived entrepreneurial desirability describes an individual's belief that he or she may flourish as a self-employed person [60,61], implying that an employment position that allows an individual to behave according to their principles is connected with success in that employment. As a result, we anticipate that people who have strong biospheric and altruistic values will have more favorable attitudes toward sustainable business. Biospheric values have been shown to have a greater impact on sustainable behavior than altruistic values [25]. However, given the importance of values such as ethical choices related to altruism to social entrepreneurship, we can expect strong associations between altruism and positive attitudes toward sustainable entrepreneurship and behavior [62]. Relationships are thus established between values (altruistic, biospheric), a mindset that adheres to sustainable entrepreneurship, perceived behavior control, and sustainable entrepreneurial intention, as inferred from the literature on personal values in the context of extrinsic rewards, intrinsic rewards, environmental values, and entrepreneurial benefits.

Hypothesis 2a (H2a). The association between high altruistic value and sustainable entrepreneurial intention will be positively mediated by attitude towards sustainability.

Hypothesis $\mathbf{2 b} \mathbf{~ ( H 2 b ) . ~ T h e ~ a s s o c i a t i o n ~ b e t w e e n ~ s t r o n g ~ a l t r u i s t i c ~ v a l u e ~ a n d ~ s u s t a i n a b l e ~ e n - ~}$ trepreneurial intention will be positively mediated by perceived behavior control.

Hypothesis 3a (H3a). The association between biospheric value and sustainable entrepreneurial intention will be positively mediated by attitudes toward sustainability.

Hypothesis $\mathbf{3 b} \mathbf{~ ( H 3 b ) . ~ T h e ~ a s s o c i a t i o n ~ b e t w e e n ~ b i o s p h e r i c ~ v a l u e ~ a n d ~ s u s t a i n a b l e ~ e n t r e p r e n e u r i a l ~}$ intention will be positively mediated by perceived behavior control.

\subsection{The Role of Self-Enhancing Values, Attitude towards Sustainable Entrepreneurship, and Perceived Behavior Control}

The second dimension concerns self-enhancement values, which indicate care for one's interests and a focus on one's expenses and rewards when making decisions. When the perceived individual benefits of such measures surpass the perceived costs, human beings with excessive self-enhancement values behave pro-environmentally $[63,64]$. Individuals strongly guided by self-transcendent values are much more likely to have pro-environmental perspectives, attitudes, choices, and behaviors, whereas those who 
display strong self-enhancement values are the reverse $[65,66]$. Research is currently being conducted to better understand environmental behavior in relation to two forms of self-enhancement value: egoistic and hedonic. Egoistic values constitute a focus on the "charges and benefits of selections that impact the assets humans have, consisting of wealth, energy, and accomplishment" [25]. Self-enhancement values, in comparison to biospheric and altruistic values, signify the proclivity to pursue personal rewards over societal or public rewards whilst making choices [25]. It is possible that egoism does not lead to unsustainable conduct. For example, if a person believes solar panels would save money, he or she may install them. As a result, as previously stated, individuals might interpret sustainable entrepreneurial activity as beneficial to themselves [67]. At the same time, to achieve a balance among the three categories of value, a certain level of egoism is essential [9]. Despite this, a past study discovered a detrimental link between egoistic ideals and sustainable behavior [58]. Additionally, Vuorio et al. [21] imply that extrinsic inducements, which can often be more materialistic, have a negative impact on attitudes towards sustainable enterprise and sustainable perceived behavior. In other words, an over-focus on self-enhancing values creates an imbalance in the triple bottom line. As a result, we argue that, even though sustainable entrepreneurs should show some egoism in order to create value for themselves, excessive egoism might also create a focus on personal gains, which may have a negative effect on attitudes toward sustainable entrepreneurship and sustainable perceived behavior control.

Finally, hedonic values refer to an individual's proclivity for ideas [25] attitudes, preferences, and behaviors that are ecologically relevant when behaving pro-environmentally involves effort or diminishes comfort. Two parts of this study support existing theories about the importance of hedonic values. First, some scholars have recognized the importance of hedonic consumption, and emphasized the importance of emotional motivations and hedonic features in consumer behavior $[15,68]$. For example, that hedonic characteristics are positively related to the likelihood of buying genetically modified food is probably anchored in hedonic values [69].

Secondly, goal-framing theory suggests that conduct is guided by three overarching objectives: (1) hedonic objectives, (2) gain objectives, and (3) normative objectives [70]. Hedonic objectives, according to Lindenberg and Steg [70], may have a substantial impact on environmental behavior since they are the strongest a priori. As a result, hedonic values may impact environmentally relevant beliefs, attitudes, preferences, and behavior, as they are likely to alter the intensity of hedonic objectives, according to goal-framing theory. As a result, such activities can sustainably boost green drive, innovation prospects, productivity, socioeconomic position, and self-reliance, particularly in developing nations, which have more potential to contribute to the achievement of sustainable development goals $[19,24]$. As previously stated, the concept of working as a sustainable entrepreneur might also provide a man or woman with a feeling of importance and empowerment if it aligns with their own ideals [64]. While this may bring some gratification, individuals may still be hesitant to establish a sustainable business owing to the additional effort that may be required to become a sustainable entrepreneur. Based on the theory of planned behavior, this study proposes that attitudes toward behavior now include attitudes toward sustainability, perceived behavioral control, and sustainable intentions (Figure 1). Students attitudes toward sustainability and personal values are proposed as elements of sustainable entrepreneurial intentions. In addition, these factors should be supplemented with personal values.

Hypothesis $4 \mathbf{a}(\mathbf{H 4 a})$. The association between strong hedonic values and sustainable entrepreneurial intention will be negatively mediated by attitude toward sustainability.

Hypothesis $4 \mathbf{b}(\mathbf{H} 4 \mathbf{b})$. The association between strong hedonic values and sustainable entrepreneurial intention will be negatively affected by perceived behavior control. 
Hypothesis 5a (H5a). The association between strong egoistic values and sustainable entrepreneurial intention will be negatively affected by attitude towards sustainability.

Hypothesis $\mathbf{5 b} \mathbf{b} \mathbf{H} 5 \mathbf{b})$. The association of strong egoistic values and sustainable entrepreneurial intention will be negatively mediated by perceived behavior control.

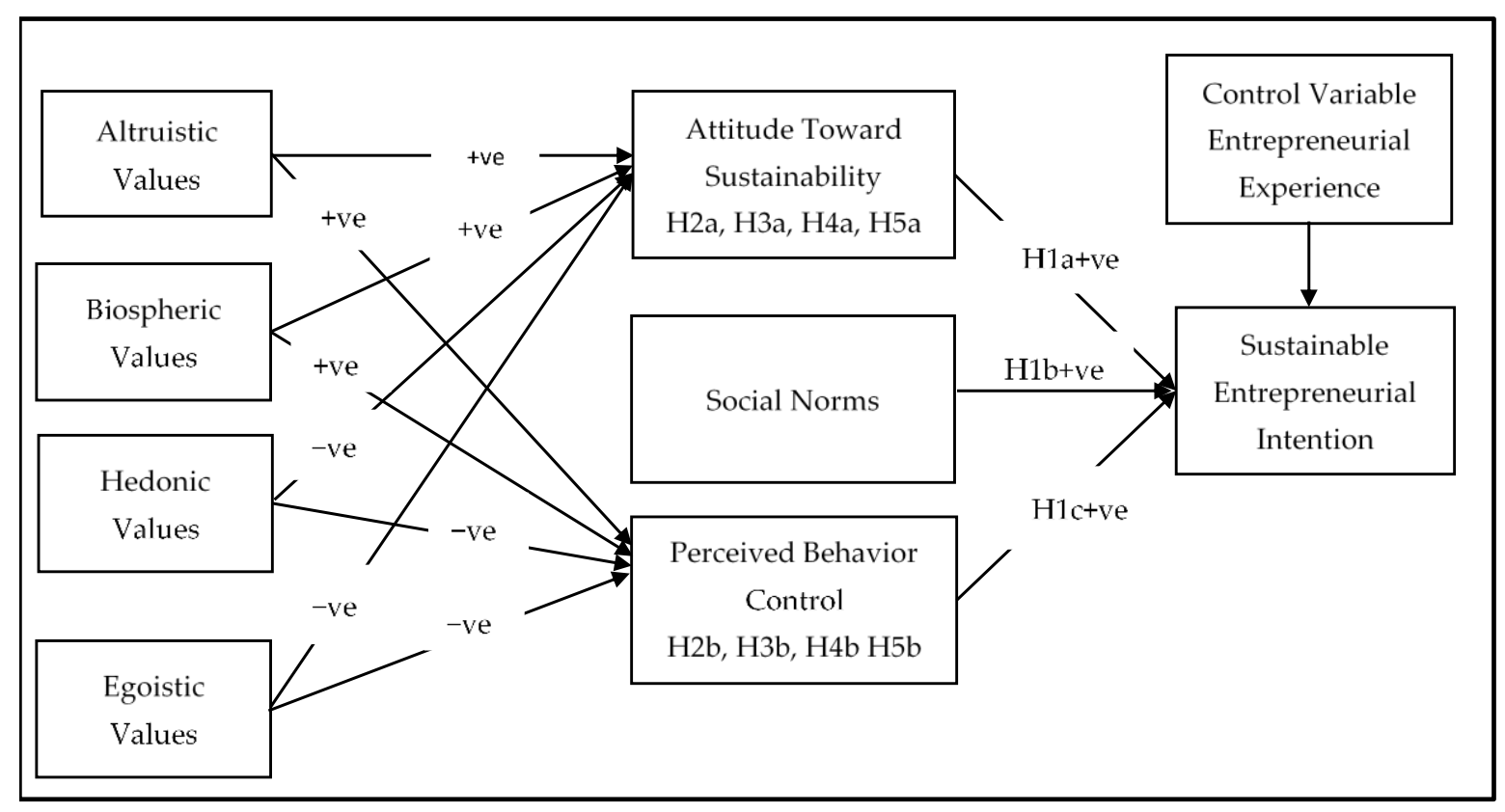

Figure 1. Research framework.

\section{Data Collection and Empirical Approach}

\subsection{Research Design}

Currently, the UNDP contains the highest recorded percentage of young people since independence, according to the report "Unleashing the Potential of Young Pakistan". About $64 \%$ (210 million) of the total population are under the age of 30 and $29 \%$ are between 15 and 29 years old [71]. If young people are properly taught in the future, they can have a decisive influence on the structure of the national economic system [72], and act as catalysts for achieving sustainable development. The data for this study were collected from enrolled university students, from August 2019 to November 2019, in various cities of the Punjab province in Pakistan. The current study employed a stratified (purposive) sampling method [73] wherein stratification was undertaken to derive a sample that was populationrepresentative. Because the respondents were collected through purposively distribution of questionnaires and asked to fill out the information. This technique enabled us to select respondents based on predetermined wisdom, provided by expert opinions in field. In addition, studies have shown that the likelihood of entrepreneurship is increased in higher education. That is why we surveyed students who were at university and were about to make a decision with regards to their future job [74]. This work employed a four-step method in the theoretical investigation [75]. To collect established measurement constructs, first, the literature was examined. Secondly, the validity of the surveys was checked by expert interviewers. Third, using a preliminary pilot survey, 30 participants assessed the reliability and consistency of the survey. Fourth, a second pilot with 55 participants in five separate universities finalized the actual data-collecting questionnaire, in terms of the validity and reliability, after a few small adjustments in phrasing and item sequencing that arose from the first pilot test. In the final questionnaire, a five-point Likert scale was provided (one strongly disagree, five strongly agree) for each of the different investigation items related to the students' entrepreneurial goals, in order to obtain essential responses. 
The intention scales were inverted, following Podsakoff and co-workers in order to prevent common method bias and to enhance the quality of data submitted by the respondents [76]. Herman's single-factor test was also employed to investigate common variations in the approach. Eight components, which represented $68 \%$ of the total variation, were found through the research. The first element in the data showed only $24 \%$ variation, so significant variation does not appear to be a common factor. This suggests that for the current investigation, common approach bias is not an important concern. The variance inflation factor (VIF) value was utilized to examine common SEM-AMOS technique bias for all eight components lacking common process basement as well as pathological collinearity, and its value was below the threshold level (3.3) [77]. Data were acquired from 577 respondents via the distribution of questionnaires and requests for information. Students were selected from the three main sectors of industry-business, engineering, and technology-in Pakistan. These three fields contribute significantly to sustainable entrepreneurship worldwide, and that is why students from these subjects were selected $[78,79]$. Since the study was primarily aimed at young people, the age range of the respondents was limited to 20 to 35 years. More importantly, the sample was made up of undergraduate students in the last semesters of their graduate degrees.

\subsection{Participants}

A total of $5 \%$ of all the questionnaires distributed were discarded due to being incomplete. This resulted in around 577 interviewees. The average age of university students enrolled in Punjab, Pakistan was 26 years (Table 1). Of the total number of responders, $60.7 \%$ were male and $39.3 \%$ female. The interviewees were mostly involved in one of three major university disciplines: engineering (51.5\%), business (34.8\%), and IT (13.7\%). In total, $24 \%$ of respondents had a background in their family business and $62 \%$ had an entrepreneurial education (Table 1).

Table 1. Profile of the respondents $(N=577)$.

\begin{tabular}{cccc}
\hline Dimensions & Category & Frequency & Percentage \\
\hline \multirow{2}{*}{ Gender } & Male & 350 & $60.7 \%$ \\
& Female & 227 & $39.3 \%$ \\
\hline \multirow{2}{*}{ Age } & $20-25$ years & 118 & $20.5 \%$ \\
& $26-30$ years & 362 & $62.7 \%$ \\
& 31-35 years & 97 & $16.8 \%$ \\
\hline \multirow{2}{*}{ Degree } & Bachelor & 233 & $40.4 \%$ \\
& Master & 325 & $56.3 \%$ \\
& others & 19 & $3.3 \%$ \\
\hline \multirow{2}{*}{ Scientific domain } & Engineering & 302 & $52.3 \%$ \\
& Business & 200 & $34.7 \%$ \\
\hline \multirow{2}{*}{ Own business } & Technology & 75 & $13.0 \%$ \\
& Yes & 143 & $24.8 \%$ \\
\hline \multirow{2}{*}{ Entrepreneurship } & No & 434 & $75.2 \%$ \\
education & Yes & 363 & $62.9 \%$ \\
\hline Total & No & 214 & $37.1 \%$ \\
\hline
\end{tabular}

\subsection{Measurement Scale}

First, Steg et al. measured the values of the 16 proposed items [25] used for the survey. This scale assesses self-transcending and self-enhancing values via four factors: (1) biospheric, (2) altruistic, (3) egoistic, and (4) hedonic value. This gauges an individual's inspiration, as well as their responsibility for helping others in society and caring for the environment. The personal value of an individual refers to their attraction to financial and personal interests, fame, power, and position. Second, this study used a modified 
version of the five items of Linan and Chen [32] to measure attitudes toward sustainable entrepreneurship. On a three-item scale of subjective norms, participants were asked to rate the degree to which family, friends and fellow students aspire to become sustainable entrepreneurs [33]. The study used Kolvereid's [80] three-item scale for sustainable entrepreneurship to measure perceived behavioral control. It was supplemented with three items taken from Linan and Chen [32]. Third, to measure intention, we used the approach of Autio et al. [81], and a three-item measure of entrepreneurial intention was also taken from the study of Linan and Chen [32]. This scale measures how individuals rate their intention to begin a sustainable business.

\subsection{Control Variable}

The current study involved pretend control variables to allow substitute descriptions of the relationships predicted in the model. In other words, it monitors participants' previous business-forming experiences. Exposure to this kind of measured entrepreneurship may lead to stronger intentions to start a new business due to higher attentiveness and self-efficacy [82].

\subsection{Analysis of the Study}

The present study was performed using SPSS 21 and AMOS for data analysis. This is because their combination is favored in the latest eco-friendly studies [83]. The study first carried out exploratory component analysis (EFA) to determine the aspect structures and factor loadings of the usage of SPSS 21. It then tested the fitness of the proposed model using confirmatory factor analysis (CFA) in AMOS, and performed path analysis to explore the association among constructs using SEM. Before EFA, the study evaluated the multivariate normality and fit of the sample collection. Due to Bartlett's sphericity test gave significant results $(p<0.05)$ and the Kaiser-Meyer-Olkin values $(0.904)$ were higher than 0.60 [84], throughout the EFA, principal component analysis using varimax rotations was executed to extract outstanding elements that were suitable for the statistics' factorability. The results from EFA show that the total variance explained was $68.21 \%$, the eigenvalues were greater than or equal to 1.0, and the factor load score of all the items was greater than or equal to 0.5 .

\section{Results of the Study}

\subsection{Reliability and Validity of the Study}

In the proposed model, the modeling of structural equations according to the proposal of Anderson and Gerbing [85] was performed in two steps: a measurement model for analysis, and a structural model. In the primary stage, the CFA was finished so to validate the reliability, convergence, and divergence of the measurement model. The second stage tests the fitness of the structural model and the hypothesis [86]. Due to the factor loading in the current study was $\geq 0.5$, the composite reliability of the constructs was significant, at $\geq 0.7$, and the average validity extracted (AVE) values of the variables were $\geq 0.50$ (Table 2) $[86,87]$. Since the square root of the AVE was larger than the square of the association between variables, the appropriateness of the discriminant validity shown in Table 3 was confirmed [88]. The goodness-of-fit assessment evaluated the following standards: the $\mathrm{x}^{2} / \mathrm{df}$ ratio had to be between 2 and 5 [89]; the CFI, TFI, and GFI values needed to be greater than 0.90 [87], and the RMSEA values had to be less than 0.08 [90]. Therefore, all the variables were justified using maximum likelihood estimation, applying CFA and using the recommended criteria $\left(x^{2}=1543.93, \mathrm{df}=463, p<0.05 ; \mathrm{x}^{2} / \mathrm{df} 3.334\right.$, $\mathrm{GFI}=0.90, \mathrm{AGFI}=0.92 ; \mathrm{CFI}=0.93 ; \mathrm{RMSEA}=0.05)$. 
Table 2. Reliability of construct items.

\begin{tabular}{|c|c|c|c|c|c|c|}
\hline Construct & Measurement Items & FL & $\mathbf{A}$ & CR & AVE & VIF \\
\hline Altruistic value [25] & $\begin{array}{l}\text { Equality: equal opportunity for all } \\
\text { Social justice: correcting injustice, caring for the weak } \\
\text { A world at peace: free of war and conflict } \\
\text { Helpful: working for the welfare of others }\end{array}$ & $\begin{array}{l}0.819 \\
0.788 \\
0.780 \\
0.771\end{array}$ & 0.79 & 0.79 & 0.62 & 1.3 \\
\hline Biospheric values [25] & $\begin{array}{l}\text { Protecting the environment: preserving nature } \\
\text { Preventing pollution: protecting natural resources } \\
\text { Unity with nature: fitting into nature } \\
\text { Respecting the earth: harmony with other species }\end{array}$ & $\begin{array}{l}0.839 \\
0.805 \\
0.793 \\
0.784\end{array}$ & 0.82 & 0.81 & 0.64 & 2.1 \\
\hline Hedonic values [25] & $\begin{array}{l}\text { Satisfaction with oneself: satisfaction, self-actualization } \\
\text { Enjoying life: enjoy leisure, food and sex, etc. } \\
\text { Pleasure: gratification of desires }\end{array}$ & $\begin{array}{l}0.871 \\
0.864 \\
0.853\end{array}$ & 0.82 & 0.70 & 0.74 & 1.1 \\
\hline Egoistic values [25] & $\begin{array}{c}\text { Social power: control over others } \\
\text { hardworking, aspiring } \\
\text { Authority: the right to lead and command } \\
\text { Influential: having an impact on people and events } \\
\text { Wealth: material possessions, money }\end{array}$ & $\begin{array}{l}0.856 \\
0.847 \\
0.844 \\
0.809 \\
0.728\end{array}$ & 0.87 & 0.90 & 0.67 & 1.4 \\
\hline $\begin{array}{l}\text { Attitude towards sustainable } \\
\text { entrepreneurship [32] }\end{array}$ & $\begin{array}{l}\text { I want to be a sustainable entrepreneur with many options } \\
\text { Being a sustainable entrepreneur will be very satisfying for me } \\
\text { I would like to start a sustainable business if I have the opportunity and resources } \\
\text { A profession as a sustainable entrepreneur is attractive to me } \\
\text { To me, a sustainable entrepreneur has more benefits than hazards }\end{array}$ & $\begin{array}{l}0.872 \\
0.839 \\
0.825 \\
0.814 \\
0.737\end{array}$ & 0.86 & 0.91 & 0.670 & 1.5 \\
\hline Social norm [33] & $\begin{array}{c}\text { Your fellow university students } \\
\text { Your university friends } \\
\text { Your close family }\end{array}$ & $\begin{array}{l}0.826 \\
0.795 \\
0.784\end{array}$ & 0.72 & 0.65 & 0.64 & 1.4 \\
\hline Perceived behavior control $[32,80]$ & $\begin{array}{l}\text { We have the knowledge you need to start a sustainable company } \\
\text { If you start a sustainable company, your chances of success are high } \\
\text { Control the process of creating new sustainable businesses } \\
\text { You can easily build your career as a sustainable entrepreneur if you wish } \\
\text { It will be very easy for me to start my company and become a sustainable entrepreneur } \\
\text { Identify market opportunities for developing new products and/or services }\end{array}$ & $\begin{array}{l}0.892 \\
0.864 \\
0.823 \\
0.796 \\
0.785 \\
0.754\end{array}$ & 0.90 & 0.92 & 0.67 & 1.7 \\
\hline $\begin{array}{l}\text { Sustainable entrepreneurial } \\
\text { intention }[32,81]\end{array}$ & $\begin{array}{l}\text { My career goal is to become a sustainable entrepreneur } \\
\text { I'm looking to start a company that will address sustainability issues in the next five years } \\
\text { If you start your own business, we will promote sustainable development } \\
\text { I use natural resources responsibly as an entrepreneur } \\
\text { If I start my own business, I will favor social goods over economic gains } \\
\text { Ready to do anything to become a sustainable entrepreneur }\end{array}$ & $\begin{array}{l}0.916 \\
0.905 \\
0.902 \\
0.901 \\
0.862 \\
0.850\end{array}$ & 0.94 & 0.95 & 0.79 & 2.6 \\
\hline
\end{tabular}

Note. $\mathrm{FL}$ = factor loading; $\mathrm{A}=$ Cronbach's Alpha; $\mathrm{CR}$ = composite reliability; $\mathrm{AVE}$ = average variance extracted; VIF = variance inflation factor. 
Table 3. Discriminant validity.

\begin{tabular}{|c|c|c|c|c|c|c|c|c|c|}
\hline & Bio. v & Alt. v & Ego. v & Hed. v & ATS & SN & PBC & SEI & EX \\
\hline Bio. v & 0.722 & & & & & & & & \\
\hline Alt. v & -0.109 & 0.526 & & & & & & & \\
\hline Ego. v & 0.930 & -0.133 & 0.724 & & & & & & \\
\hline Hed. v & 0.041 & 0.265 & 0.084 & 0.555 & & & & & \\
\hline ATS & 0.022 & 0.487 & 0.013 & 0.301 & 0.754 & & & & \\
\hline SN & 0.526 & 0.079 & 0.528 & 0.032 & 0.483 & 0.910 & & & \\
\hline PBC & -0.058 & 0.189 & -0.102 & -0.020 & 0.682 & 0.631 & 0.748 & & \\
\hline SEI & -0.136 & -0.085 & -0.151 & -0.324 & -0.156 & -0.208 & -0.145 & 0.571 & \\
\hline $\mathrm{EX}^{\mathrm{a}}$ & -0.152 & -0.088 & -0.198 & -0.352 & -0.168 & -0.079 & -0.079 & 0.701 & 0.549 \\
\hline
\end{tabular}

Bio. v = biospheric values; Alt. v = altruistic value; Ego. v = egoistic values; Hed. v = hedonic values; ATS = attitude towards sustainability; $\mathrm{SN}=$ social norms; PBC = perceived behavior control; SEI = sustainable entrepreneurial intention; $\mathrm{EX}^{\mathrm{a}}=$ entrepreneurial experience (control variable).

\subsection{Assessment of Goodness-of-Fit}

SEM was performed on the proposed model in the structural model. A structural model was obtained to fit the data of the proposed model after SEM $\left(x^{2}=1643.93, \mathrm{df}=573\right.$, $p<0.05 ; \mathrm{x}^{2} / \mathrm{df} 2.86$, AGFI $=0.94, \mathrm{GFI}=0.91, \mathrm{NFI}=0.93 ; \mathrm{CFI}=0.92 ; \mathrm{RMSEA}=0.05$ ). The proposed model achieved better goodness-of-fit results. Furthermore, the proposed model showed greater predictive power for individual values $\left(R^{2}=0.568\right)$, which included goodness-of-fit statistics are mentioned in Table 4.

Table 4. Goodness-of-fit statistics of the model.

\begin{tabular}{cccc}
\hline The Goodness-of-Fit Measure & $\begin{array}{c}\text { Recommended } \\
\text { Values }\end{array}$ & $\begin{array}{c}\text { Structural Model } \\
\text { Results }\end{array}$ & Source \\
\hline $\mathrm{x}^{2}$ & $p<0.05$ & 1643.934 & 573 \\
$\mathrm{df}$ & $>3.0$ & 2.86 \\
$\mathrm{x}^{2}$ test statistic/df & $>0.90$ & 0.94 \\
AGFI (Adjusted & $>0.90$ & 0.91 \\
Goodness-of-Fit Index) & $>0.90$ & 0.92 \\
GFI (Goodness-of-Fit Index) & $>0.90$ & 0.93 \\
CFI (Comparative Fit Index) & $<0.08$ & 0.05 & \\
NFI (Normed Fit Index) & & 0.568 & \\
RMSEA (Root Mean Square & &
\end{tabular}

\subsection{Direct Effect of the Construct}

To understand the significance of self-enhancing and self-transcending values and the sustainable entrepreneurial intention-based framework for a developing country, an assessment was performed with a minimum of 1000 subsamples using the bootstrapping method. The factor loading and path model results and the values of their significance to each other are given in Figure 2 and Table 5. 


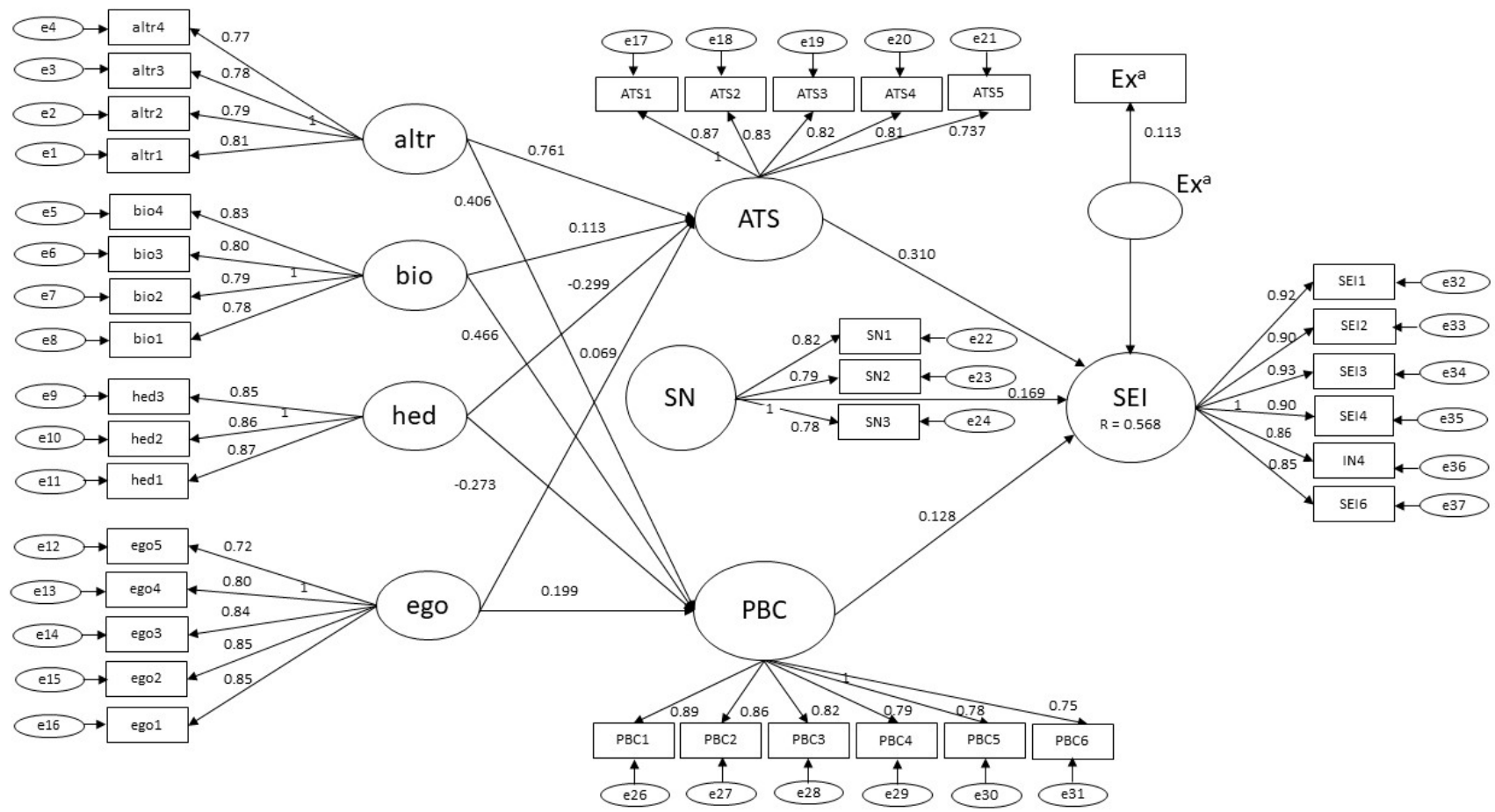

Figure 2. Result of the measurement and structural model.

Table 5. Direct effect of the constructs.

\begin{tabular}{ccccc}
\hline Constructs & Direct Effect & t-Value & Hypotheses & Significant \\
\hline ATS $\rightarrow$ SEI & 0.310 & 2.725 & H1a & YES \\
SN $\rightarrow$ SEI & 0.169 & 2.897 & H1b & YES \\
PBC $\rightarrow$ SEI & 0.128 & 3.137 & H1c & YES \\
Alt. $\mathrm{v} \rightarrow$ ATS & 0.276 & 3.740 & & YES \\
Bio. $\mathrm{v} \rightarrow$ ATS & 0.113 & 3.542 & & YES \\
Hed. $\mathrm{v} \rightarrow$ ATS & 0.299 & 3.487 & & YES \\
Ego. $\mathrm{v} \rightarrow$ ATS & -0.061 & -1.381 & & NO \\
Alt. $\mathrm{v} \rightarrow$ PBC & 0.406 & 5.196 & & YES \\
Bio. $\mathrm{v} \rightarrow$ PBC & 0.466 & 5.846 & & Yes \\
Hed. $\mathrm{v} \rightarrow$ PBC & -0.273 & 2.787 & & Yes \\
Ego. $\mathrm{v} \rightarrow$ PBC & -0.199 & -1.797 & & NO \\
Ent. Experience & 0.113 & 3.542 & Control variable & YES
\end{tabular}

ATS = attitude towards sustainability; SN = social norms; PBC = perceived behavior control; Alt. $\mathrm{v}=$ altruistic values Bio. $\mathrm{v}=$ biospheric values; Hed. $\mathrm{v}=$ hedonic values; Ego. $\mathrm{v}=$ egoistic values; Ent. Experience $=$ entrepreneurial experience; ${ }^{\mathrm{a}}=$ control variable.

In the first hypothesis, $\mathrm{H1}$, an important relationship is proposed between the three dimensions of TPB when determining the intention to launch a new sustainable business. Figure 2 shows that the pathway coefficients for intention to become a sustainable entrepreneur (ATS; $\beta$ 0.310, $t=2.725$ ) and perceived behavioral control (PBC; $\beta 0.128$, $t=3.137$ ) were positive and significant. Pathway coefficients from the subjective norm to intention were also significant $(\mathrm{SN} ; \beta 0.169, \mathrm{t}=2.897)$. H1 is thus supported by the data. Interestingly, the support of social networks was shown to be very important. This is consistent with previous results reported in the established entrepreneurship literature [14].

Second, the results show that altruistic (Alt; $\beta 0.276, t=3.740$ ) and biospheric (Bio; $\beta$ $0.113, t=3.542$ ) values have a direct and positive effect on ATS, whereas hedonistic (Hed; $\beta 0.299, t=3.487)$ values and egoistic (ego; $\beta-0.061, t=-1.381$ ) values have the opposite effect. These results are consistent with the current literature on the intentions or behaviors of individual firms that tend to value power, independence, risk-taking, and innovative power [38]. Furthermore, the results suggest a non-significant relationship between egoistic values and attitudes towards sustainable entrepreneurship. Concerning the significant 
positive correlations between altruistic, biospheric, and hedonistic values, and attitudes towards sustainable entrepreneurship, the results align with the present literature [92].

Third, the results also support the direct relationship of altruistic (Alt; $\beta 0.406 \mathrm{t}=5.196$ ) and biospheric (Bio; $\beta$ 0.466, $t=5.196)$ values with PBC. These results are also supported in the literature on altruistic and biospheric values, which have positive associations with entrepreneurial intentions [93]. Here, altruistic and biospheric values are identified as positive drivers of sustainability intentions. Regarding the role of hedonic (Hed; $\beta 0.273, t=2.787$ ) and egoistic (Ego; $\beta-0.199, \mathrm{t}=-3.542$ ) values in sustainable entrepreneurial intentions, the results show that egoistic and hedonic values have positive effects on and significant relationships with PBC. Egoistic values transfer the negative antecedents of sustainable intentions to sustainable organization. The previous literature on entrepreneurial intentions is consistent with these consequences, and shows that entrepreneurs with advanced egoistic values have less effect compared to others who pay greater attention to innovation and individuality in terms of lowering sustainable entrepreneurial intentions [94].

Finally, a strong predictor of intentions to act as a sustainable entrepreneur is previous entrepreneurial experience. Given that the outcomes for the control variable were in agreement with our expectations, the path coefficient of the control variable become positive and significant $(\beta 0.113, \mathrm{t}=3.542)$ [82].

\subsection{Testing Hypothesis and Path Analysis}

The literature has shown that theory can play a role in directly assessing attitudes toward sustainable entrepreneurship, and whether these are due to an individual's ability to exhibit sustainable behavior [95]. Additionally, previous research suggests that the linear relationship between desirability, feasibility, and intention, as stated within the $\mathrm{TPB}$, may be more complicated for sustainable entrepreneurship [21]. In this article, an indirect effect analysis method was used to test mediation [96]. A bootstrapping analysis with 1000 subsamples was performed on the samples, which conclusively proved the indirect effect results. Therefore, the mediation effect of the proposed connection was tested using SEM-AMOS. The mediation test employed the criteria of Zhao, Lynch, and Chen [96] to determine the kind of mediation required, following the proposed hypothesis that indicated the mediating role of SEI, as well as ATS and PBC as self-transcending (altruistic and biospheric) and self-enhancing (hedonic and egoistic) values. The five types of mediation effects presented by Zhao, Lynch, and Chen were complementary mediation; competitive mediation; indirect only mediation; direct only non-mediation; and no-effect non-mediation [96]. The partial and full mediation of Baron and Kenney [97] is similar to the complementary and indirect mediation of Zhao, Lynch and Chen [96]. The importance values, and each parameter of each direct path (Table 5), played a role in predicting the mediating effect of self-transcending (altruistic and biosphere) and self-enhancing (hedonic and egoistic) values on SEI. Both the direct and indirect effects of the variations and types of mediation are that significant partial mediation is achieved.

Similarly, ATS positively mediates the relationship between altruistic, biospheric, hedonistic, and egoistic values, and SEI. However, it does not convey the indirect negative relationship between egoistic values and SEI. Therefore, $\mathrm{H} 2 \mathrm{a}, \mathrm{H} 3 \mathrm{a}$, and $\mathrm{H} 4 \mathrm{a}$ are supported by the study, and H5a is not, because it does not show any significant mediating relationship with ATS. This indicates that the higher the motivation and preference for altruistic, biospheric, and hedonistic values, the higher the SEI, as ATS converts altruistic, biospheric, and hedonistic values into SEI.

The mediation, in the context of path analysis, has an indirect effect on the dependent variable through one or two mediation variables [98]. As can be seen in the results, PBC fully mediates the suggested path between altruistic, biospheric, hedonistic, and egoistic value and the SEI. Altruism and biosphere are indirectly positive, while hedonistic values have an indirect negative impact on students' SEI. This study also does not suggest an indirect negative association between egoist values and SEI. Thus, the proposed hypotheses 
$\mathrm{H} 2 \mathrm{~b}, \mathrm{H} 3 \mathrm{~b}$ and $\mathrm{H} 4 \mathrm{~b}$ are accepted, and $\mathrm{H} 5 \mathrm{~b}$ is not accepted, because it is not significantly mediated by PBC (Table 6).

Table 6. Testing Mediation Effect.

\begin{tabular}{ccccccc}
\hline \multicolumn{1}{c}{ Path } & Coefficient & $p$-Value & L.T & U.T & Hypothesis & Mediation Types \\
\hline AL $\rightarrow$ ATS $\rightarrow$ SEI & 0.97 & 0.000 & 0.056 & 0.141 & H2a & Complementary partial mediation \\
Bio $\rightarrow$ ATS $\rightarrow$ SEI & 0.058 & 0.001 & 0.027 & 0.098 & H3a & Complementary partial mediation \\
Hed $\rightarrow$ ATS $\rightarrow$ SEI & 0.037 & 0.003 & 0.015 & 0.066 & H4a & Complementary partial mediation \\
Ego $\rightarrow$ ATS $\rightarrow$ SEI & 0.031 & 0.146 & 0.010 & 0.071 & H5a & No effect \\
AL $\rightarrow$ PBC $\rightarrow$ SEI & 0.086 & 0.000 & 0.045 & 0.135 & H2b & Complementary partial mediation \\
Bio $\rightarrow$ PBC $\rightarrow$ SEI & 0.036 & 0.005 & 0.014 & 0.066 & H3b & Complementary partial mediation \\
Hed $\rightarrow$ PBC $\rightarrow$ SEI & 0.035 & -0.004 & 0.015 & 0.063 & H4b & competitive mediation \\
Ego $\rightarrow$ PBC $\rightarrow$ SEI & 0.001 & 0.838 & -0.009 & 0.016 & H5b & No effect \\
\hline
\end{tabular}

\section{Discussion}

AMOS created the proposed relationships (direct and indirect) between constructs based on structural model estimation. Figure 2 offers the results and precisely demonstrates the important positive associations, as follows: First, the current results are consistent with $\mathrm{TPB}$, suggesting that the sustainable entrepreneurial intentions of ATS, SN, and PBC students were fully activated. Therefore, these results fully support the direct association between the three mediating parameters (ATS, SN, PBC), and sustainable entrepreneurial intention. These results are consistent with those previously reported [99,100], which reinforces our belief that sustainable entrepreneurial intention is more complex than a linear association.

Secondly, when behaviors are associated with egoistic and hedonic outcomes, such as automatic car use measures, they impart both egoistic and hedonic value on the attitudes and behaviors involved. Hedonic values are critical in predicting attitudes and behaviors when egoistic values are managed, suggesting that both values impact attitudes and behaviors independently and replicate special elements of attitudes and behaviors within the environmental sphere. This helps them cope with the complexity that arises from meeting the triple bottom line of social, ecological, and economic value creation, considering that the sustainable entrepreneurial intentions identified in the previous research suggest that companies oriented towards sustainable entrepreneurship need a sustainability direction [101].

Second, the study intellectualized and quantified this complexity using a value system. We have supplemented previous research that focused on the value of work as a determinant of sustainable entrepreneurial intentions [21]. Most significantly, the previous measures of altruism did not differentiate between altruism towards other individuals (social altruism) and altruism towards the surroundings (biospheric altruism). The current research demonstrates the importance of altruistic and biospheric values and their impact on attitudes toward sustainable entrepreneurship. This suggests that altruism, or the desire to increase the well-being of others, is not enough as an explanation for sustainable entrepreneurial intentions, and it must be differentiated from respect for the environment [9]. This research invites future studies to explore whether similar cognitive instruments, such as perception or empathic attention [56,57], help develop pro-ecological attitudes and subsequent sustainable entrepreneurial intentions. The study's approach has also proven that egoistic values play an insignificant role in this value. This is because of the role of altruistic value in sustainable entrepreneurship, rather than being due to the individual acting out of enlightened selfishness [102], which may suggest that personal interests and business aspects are secondary means to an end [51,52]. However, this study only discussed general sustainable entrepreneurial intentions. Therefore, it was not possible to distinguish between the development opportunities that participants considered desirable. Thus, individuals perceive their sustainable and financial desires as synergistic effects and want people to act altruistically for their advantage [54]. The study invites future research 
to explore the relationship between intention and opportunity in relation to altruism. Instead of a hypothetical negative effect, the results of the current study confirm that hedonic values have a positive impact on attitudes toward sustainable entrepreneurship. This suggests that, as long as sustainable entrepreneurship can potentially balance the cost of individual economic losses, individuals can still become sustainable entrepreneurs $[38,103]$.

Third, the results show that PBC (perceived behavior control) entirely mediates the relationship between self-transcending and self-enhancing values and SEI. These hypothetical indirect effects were shown to be significant by the bootstrap analysis results. The results show that altruistic and biospheric values have a direct and positive impact on PBC, while hedonic and egoistic values have a contradictory influence on it. Consequently, compared to the present literature on personal entrepreneurial intentions and behavior, these results are more consistent, showing that, together with power, independence, risktaking, and innovation capacity $[50,104]$, altruistic and biospheric values have positive and significant effects on sustainable entrepreneurial intentions in New Zealand and the USA. This suggests that altruism or desire to improve the well-being of others alone is not adequate to explain sustainable business intentions and depends on consideration of the environment. These study outcomes show that the well-being of others, and the valuation of power, independence, risk-taking, and innovation, should be accompanied by concern for the environment. The study subjects showed their intention to be the sustainable entrepreneurs of the future. Regarding the role of hedonic values in sustainable entrepreneurial intentions, the results show a negative association with PBC, and that hedonic values are negative precursors of sustainable entrepreneurial intentions. These results are also consistent with the previous works on entrepreneurial intentions and show that people with higher hedonistic (personal gain) values tend to have less sustainable entrepreneurial intentions than others who place greater emphasis on innovation and independence [94]. Having egoistic values does not provide a basis for mediation, as it is not related to $\mathrm{PBC}$ and therefore cannot meet the requirements of the mediation analysis recommended by Zhao, Lynch, and Chen [96]. However, people with strong egoistic values were shown to be less likely to choose a restaurant based on food palatability when hedonistic values were considered.

Fourth, the relatively low rates of sustainable entrepreneurship may suggest that individuals are less exposed to sustainable entrepreneurship than conventional entrepreneurship [20]. Thus, people who are subject to entrepreneurial exposure are more likely to start a business because of higher levels of alertness and self-efficacy, a more positive attitude toward self-reliance and behavior, and their use of families and friends as role models $[14,82]$.

\subsection{Theoretical Implication}

Since the first definition given by Ajzen [26], the theory of planned behavior (TPB) has been tested in various environmental psychology studies over the years. However, since the value theory of Schwartz [105] was proposed, it has been less widely accepted in research. This study contributes to the literature on sustainable entrepreneurial intention (SEI) in several ways. First, the current study provides evidence for how well TPB and self-transcendence and self-enhancement values can be integrated to explain sustainable entrepreneurial intentions.

Second, sustainable entrepreneurs are normally visible as key drivers of sustainable innovation, helping the transition towards a more circular economic system $[10,12,44]$. In past research, the human aspect of the circular economic system has been placed at the forefront [44], emphasizing human resource practices $[12,44]$ or environmental training in the workplace [106].

Third, we looked at former studies enclosing a sustainable entrepreneurship curriculum. It has been proven that attending certain sustainable entrepreneurship design courses is positively related to sustainable entrepreneurship [107]. 
Fourth, the strongest determinant of SEI was PBC (perceived behavior control), as was consistent with previous pragmatic studies [108]. This research indicates that the question of how effectively people can take control of perceived behavior and address obstacles to environmentally friendly behavior is a crucial component in determining sustainable intentions and behaviors, as well as establishing a sense of moral obligation as regards behavior. A more theoretical implication of this present study is that altruistic and biospheric values are significant determinants of TPB structure and are predictors of subjective norms for SEI.

\subsection{Practical Implication}

The current research affects entrepreneurship sustainability, and the content of engineering, business, and technology courses at universities [109]. Values are generally considered to be relatively stable [105]. For example, little change is seen in non-biospherically inclined individuals. But there are ways to activate your potential values. This can help increase an individual's propensity to respond to their latent values.

This study delineates the essential implications of the positive and significant mediating effects of attitudes on sustainable entrepreneurship and perceived behavioral control. It suggests that an internal balance of values, perceived abilities, and motivations is associated with sustainable entrepreneurship. These results suggest that SEI development will also be more advanced when individuals have stronger personal values themselves. Therefore, improving skills and abilities is a viable option for promoting sustainable entrepreneurship and creating sustainable graduates.

In the context of developing countries, this study highlights the need to incorporate self-transcending and self-enhancing values into the realm of sustainability, and to develop an attitude towards sustainable entrepreneurship in order to produce young entrepreneurs with sustainable intentions. In this way, sustainable opportunities will strengthen sustainable entrepreneurial intentions and promote sustainable entrepreneurship in developing countries. To this end, the research uses and interacts with the experiences of role models in this field to convey a positive picture of sustainable intentions so to encourage the development of sustainable entrepreneurship.

One method to accomplish this is to incorporate these foundations into the initial phases of a sustainable entrepreneurial curriculum, such as an undergraduate course. When decisions are made to become sustainable entrepreneurs, the general and technical knowledge that is developed can become the focus of postgraduate studies [109]. Therefore, the study recommends the value activation strategies presented above. This can help to more effectively target individuals in the classroom.

\subsection{Future Research}

This study has several limitations, each of which opens additional opportunities for future study. First, contemporary studies did not look at the role of gender. However, the inclusion of gender roles, particularly in developing international locations, will further support the model established here.

Second, one region in Pakistan was used, meaning that the sample is limited, and more large-scale studies are needed to generalize the results. Due to the current study's sampling method was limited to convenience sampling, future researchers could employ more demonstrative sampling methods and better measurement tools. Therefore, future studies could expand the sample coverage to include young people from other cities and regions.

Third, there is no relationship between intention and actual action, which is wellknown as a limitation of entrepreneurial intention studies [14]. Just because a person has an intention to engage in a specific action does not always imply that they will fulfil that intention. This study provides an important starting point for future intention and actual behavioral studies, including the possibility of longitudinal studies that analyze variations in intention over time, and the consequences of behavior. 
Fourth, the measurement items were limited by the information obtained through the survey. Building on previous studies, some of which were adapted to specific research contexts, this study relied on well-known measures. Replicating this research with new statistics would enable cross-validation and enhanced measures. Future research may incorporate the content of sustainable entrepreneurship curricula to analyze educational content that will aid in intention formation $[110,111]$. The use of a mixed study design, especially involving longitudinal case studies with the effects stated here, may hold potential.

\subsection{Conclusions}

Despite advances in entrepreneurship and the significant transition from the earliest ventures to the most modern ones, there may nonetheless be a lack of evidence for the unique roles of intentions and various values in all kinds of entrepreneurship. The purpose of this paper is to empirically address the complexity of the intention-building method of sustainable entrepreneurship that arises from the pursuit of the triple bottom line: social, ecological, and economic goals. This complexity arises from potentially conflicting goals and can prevent an individual from starting a sustainable enterprise. The current research shows that, by discussing distinctive personal (self-enhancing and self-transcending) values, different attitudes toward sustainable entrepreneurship and perceived behavioral control can be explained. The research findings offer useful insights that help endorse sustainable entrepreneurship among up-and-coming entrepreneurs. The current study attempts to validate the critical and effective mediating consequences of attitudes towards sustainable entrepreneurship and perceived behavioral control and suggests practical and policy-based approaches to improving sustainable entrepreneurship. It accordingly helps to explain the values people develop whilst trying to balance the selfishness and altruism inherent in sustainable entrepreneurial behavior. Through value activation approaches, these outcomes can be combined into educational programs, thus complementing the sustainable entrepreneurial skills and competencies being taught. We hope that our results provide an exciting avenue for research, and help practitioners develop the potential of sustainable entrepreneurialism, as this is a driving force behind the development towards a more innovation-driven circular economy.

Author Contributions: Conceptualization, N.Y.; methodology, N.Y. and N.M.; software, N.Y., N.M., H.S.M. and O.R.; validation, N.Y., N.M. and H.S.M.; investigation, N.Y., N.M., H.S.M., O.R. and A.L.; resources, N.Y. and N.M.; data curation, N.Y., N.M., H.S.M., O.R. and A.L.; writing-original draft preparation, N.Y. and N.M.; writing—review and editing, N.Y. and A.L.; visualization, N.Y., N.M. and A.L.; supervision, A.L. All authors have read and agreed to the published version of the manuscript.

Funding: This research received no external funding.

Institutional Review Board Statement: All procedures followed in this research were in accordance with the ethical standards of the responsible committee on human experimentation (Northwest University, Xi'an, 710127, Shaanxi, China) and with the Helsinki Declaration of 1975, as revised in 2000. This approval was taken on 18 May 2020.

Informed Consent Statement: Written informed consent was obtained from all participants to be included in the study.

Data Availability Statement: The quantitative and qualitative data used to support the findings of this study are included within the article.

Conflicts of Interest: The authors declare no conflict of interest.

\section{References}

1. Hockerts, K.; Wustenhagen, R. Greening Goliaths versus emerging Davids theorizing about the role of incumbents and new entrants in sustainable entrepreneurship. J. Bus. Ventur. 2010, 25, 481-492. [CrossRef]

2. Pankov, S.; Velamuri, V.K.; Schneckenberg, D. Towards sustainable entrepreneurial ecosystems: Examining the effect of contextual factors on sustainable entrepreneurial activities in the sharing economy. Small Bus. Econ. 2019, 56, 1073-1095. [CrossRef]

3. Adrita, U.W.; Mohiuddin, M.F. Impact of opportunity and ability to translate environmental attitude into ecologically conscious consumer behavior. J. Market. Theory Pract. 2020, 28, 173-186. [CrossRef] 
4. Taufique, K.M.R.; Vaithianathan, S. A fresh look at understanding green consumer behavior among young urban Indian consumers through the lens of Theory of Planned Behavior. J. Clean. Prod. 2018, 183, 46-55. [CrossRef]

5. Lawal, F.A.; Worlu, R.E.; Ayoade, O.E. Critical Success Factors for Sustainable Entrepreneurship in SMEs: Nigerian Perspective. Mediterr. J. Soc. Sci. 2016, 7, 338.

6. Parrish, B.D. Sustainability-driven entrepreneurship: Principles of organization design. J. Bus. Ventur. 2010, 25, 510-523. [CrossRef]

7. Yasir, N.; Mahmood, N.; Mehmood, H.S.; Babar, M.; Irfan, M.; Liren, A. Impact of environmental, social values and the consideration of future consequences for the development of a sustainable entrepreneurial intention. Sustainibility 2021, 13, 2648. [CrossRef]

8. Dean, T.J.; McMullen, J.S. Toward a theory of sustainable entrepreneurship: Reducing environmental degradation through entrepreneurial action. J. Bus. Ventur. 2007, 21, 50-79. [CrossRef]

9. Shepherd, D.A.; Patzelt, H. The new field of sustainable entrepreneurship: Studying entrepreneurial action linking "what is to be sustained" with "what is to be developed". Enterp. Theor. Pract. 2011, 35, 137-163. [CrossRef]

10. Veleva, V.; Bodkin, G. Corporate-entrepreneur collaborations to advance a circular economy. J. Clean. Prod. 2018, 188, 20-37. [CrossRef]

11. Eikelenboom, M.; de Jong, G. The impact of dynamic capabilities on the sustainability performance of SMEs. J. Clean. Prod. 2019, 235, 1360-1370. [CrossRef]

12. Singh, S.K.; Del Giudice, M.; Chierici, R.; Graziano, D. Green innovation and environmental performance: The role of green transformational leadership and green human resource management. Technol. Forecast. Soc. Chang. 2020, 150, 119762. [CrossRef]

13. Choi, D.; Johnson, K.K. Influences of environmental and hedonic motivations on intention to purchase green products: An extension of the theory of planned behavior. Sustain. Prod. Consump. 2019, 18, 145-155. [CrossRef]

14. Krueger, N.F.; Reilly, M.D.; Carsrud, A.L. Competing models of entrepreneurial intentions. J. Bus. Ventur. 2000, 15, 411-432. [CrossRef]

15. Kim, S.H.; Seock, Y.K. The roles of values and social norm on personal norms and pro-environmentally friendly apparel product purchasing behavior: The mediating role of personal norms. J. Retail. Consum. Serv. 2019, 51, 83-90. [CrossRef]

16. Fayolle, A.; Liñán, F.; Moriano, J.A. Beyond entrepreneurial intentions: Values and motivations in entrepreneurship. Int. Entrep. Manag. J. 2014, 10, 679-689. [CrossRef]

17. Zhang, X.; Geng, G.; Sun, P. Determinants and implications of citizens' environmental complaint in China: Integrating theory of planned behavior and norm activation model. J. Cleaner Prod. 2017, 166, 148-156. [CrossRef]

18. Yasir, N.; Mahmood, N.; Jutt, A.A.; Babar, M.; Irfan, M.; Jamil, F.; Shaukat, M.Z.; Khan, H.M.; Liren, A. How can entrepreneurial self-efficacy, proactivity and creativity enhance sustainable recognition opportunity? The effect of entrepreneurial alertness is to mediate the formation of sustainable entrepreneurial intention. Rev. Argent. Clin. Psicol. 2020, 29, $1004-1023$.

19. Munoz, P.; Cohen, B. Sustainable entrepreneurship research: Taking stock and looking ahead. Bus. Strat. Environ. 2018, 27, 300-322. [CrossRef]

20. Global Entrepreneurship Monitor. Special Topic Report Social Entrepreneurship. 2016. Available online: http://gemconsortium. org/report/49542 (accessed on 28 August 2019).

21. Vuorio, A.M.; Puumalainen, K.; Fellnhofer, K. Drivers of entrepreneurial intentions in sustainable entrepreneurship. Int. J. Entrep. Behav. Res. 2018, 24, 359-381. [CrossRef]

22. Hendrik, N.; de Jong, G. The impact of values and future orientation on intention formation within sustainable entrepreneurship. J. Clean. Prod. 2020, 266, 122052.

23. Linan, F.; Fayolle, A. A systematic literature review on entrepreneurial intentions: Citation, thematic analyses, and research agenda. Int. Enterp. Manag. J. 2015, 11, 907-933.

24. Dees, J.G. The meaning of social entrepreneurship. In Case Studies in Social Entrepreneurship and Sustainability; Routledge: London, UK, 2017; pp. 34-42.

25. Steg, L.; Perlaviciute, G.; Van der Werff, E.; Lurvink, J. The significance of hedonic values for environmentally relevant attitudes, preferences, and actions. Environ. Behav. 2014, 46, 163-192. [CrossRef]

26. Ajzen, I. The theory of planned behavior. Organ. Behav. Hum. Decis. Process. 1991, 50, 179-211. [CrossRef]

27. Maria da Silva, E.M.; Ramos, M.O.; Alexander, A.; Jabbour, C.J.C. A systematic review of empirical and normative decision analysis of risk in sustainability related supplier risk management. J. Clean. Prod. 2020, 244, 118808. [CrossRef]

28. Dhahri, S.; Omri, A. Entrepreneurship contribution to the three pillars of sustainable development: What does the evidence really say? World Dev. 2018, 106, 64-77. [CrossRef]

29. Amjad, T.; Abdul Rani, S.H.; Sa'atar, S. A new dimension of entrepreneurial marketing and key challenges: A case study from Pakistan. SEISENSE J. Manag. 2020, 3, 1-14. [CrossRef]

30. Clark, K.; Ramachandran, I. Subsidiary entrepreneurship and entrepreneurial opportunity: An institutional perspective. J. Int. Manag. 2019, 25, 37-50. [CrossRef]

31. Gorgievski, M.J.; Stephan, U.; Laguna, M.; Moriano, J.A. Predicting entrepreneurial career intentions: Values and the theory of planned behavior. J. Career Assess. 2018, 26, 457-475. [CrossRef]

32. Linan, F.; Chen, Y.W. Development and Cross-Cultural application of a specific instrument to measure entrepreneurial intentions. Enterp. Theor. Pract. 2009, 3, 593-617. [CrossRef] 
33. Nordin, R.; Hassan, R.A. The role of opportunities for green entrepreneurship towards investigating the practice of green entrepreneurship among SMEs in Malaysia. RIBER 2019, 8, 99-116.

34. Teran-Yepez, E.; Marín-Carrillo, G.M.; Casado-Belmonte, M.; del Pilar Casado-Belmonte, M.; de las Mercedes Capobianco-Uriarte, M. Sustainable entrepreneurship: Review of its evolution and new trends. J. Clean. Prod. 2020, 252, 119742. [CrossRef]

35. Si, H.; Shi, J.G.; Tang, D.; Wu, G.; Lan, J. Understanding intention and behavior toward sustainable usage of bike sharing by extending the theory of planned behavior. Resour. Conserv. Recycl. 2020, 152, 104513. [CrossRef]

36. Schick, H.; Marxen, S.; Freimann, J. Sustainability in the start-up process. In Making Ecopreneurs: Developing Sustainable Entrepreneurship; CRC Press: Boca Raton, FL, USA, 2016; pp. 108-121.

37. Gao, L.; Wang, S.; Li, J.; Li, H. Application of the extended theory of planned behavior to understand individual's energy saving behavior in workplaces. Resour. Conserv. Recycl. 2017, 127, 107-113. [CrossRef]

38. Steg, L.; Bolderdijk, J.W.; Keizer, K.; Perlaviciute, G. An integrated framework for encouraging pro-environmental behaviour: The role of values, situational factors and goals. J. Environ. Psychol. 2014, 38, 104-115. [CrossRef]

39. Schwartz, S.H. Are there universal aspects in the structure and contents of human values? J. Soc. Issues 1994, 50, 19-45. [CrossRef]

40. De Groot, J.I.M.; Steg, L. Relationships between value orientations, self-determined motivational types and pro-environmental behavioral intentions. J. Environ. Psychol. 2010, 30, 368-378. [CrossRef]

41. Morales, C.; Holtschlag, C.; Masuda, A.D.; Marquina, P. In which cultural contexts do individual values explain entrepreneurship? An integrative values framework using Schwartz's theories. Int. Small Bus. J. 2019, 37, 241-267. [CrossRef]

42. Fishbein, M.; Ajzen, I. Predicting and Changing Behavior: The Reasoned Action Approach; Taylor \& Francis: New York, NY, USA, 2009.

43. Wagner, M. Ventures for the public good and entrepreneurial intentions: An empirical analysis of sustainability orientation as a determining factor. J. Small Bus. Enterp. 2012, 25, 519-531. [CrossRef]

44. Jabbour, C.J.C.; Sarkis, J.; de Sousa Jabbour, A.B.L.; Renwick, D.W.S.; Singh, S.K.; Grebinevych, O.; Kruglianskas, I.; Godinho Filho, M. Who is in charge? A review and a research agenda on the 'human side' of the circular economy. J. Clean. Prod. 2019, 222, 793-801. [CrossRef]

45. Zhang, B.; Yang, S.; Bi, J. Enterprises' willingness to adopt/develop cleaner production technologies: An empirical study in Changshu, China. J. Clean. Prod. 2013, 40, 62-70. [CrossRef]

46. Muñoz, P.; Dimov, D. The call of the whole in understanding the development of sustainable ventures. J. Bus. Ventur. 2015, 30, 632-654. [CrossRef]

47. Abbas, J. Impact of total quality management on corporate green performance through the mediating role of corporate social responsibility. J. Clean. Prod. 2020, 242, 118458. [CrossRef]

48. Ajzen, I. Perceived Behavioral Control, Self-Efficacy, Locus of Control, and the Theory of Planned Behavior. J. Appl. Soc. Psychol. 2002, 32, 665-683. [CrossRef]

49. Chan, H.W.; Pong, V.; Tam, K.P. Explaining participation in Earth Hour: The identity perspective and the theory of planned behavior. Clim. Chang. 2020, 158, 309-325. [CrossRef]

50. Kirkley, W.W. Entrepreneurial behaviour: The role of values. Int. J. Entrep. Behav. Res. 2016, 22, 290-328. [CrossRef]

51. Schaltegger, S.; Wagner, M. Sustainable entrepreneurship and sustainability innovation: Categories and interactions. Bus. Strat. Environ. 2011, 20, 222-237. [CrossRef]

52. Santos, F.M. A positive theory of social entrepreneurship. J. Bus. Ethics 2012, 111, 335-351. [CrossRef]

53. Jahanshahi, A.A.; Brem, A.; Bhattacharjee, A. Who takes more sustainability oriented entrepreneurial actions? The role of entrepreneurs' values, beliefs and orientations. Sustainability 2017, 9, 1636. [CrossRef]

54. De Waal, F.B. Putting the altruism back into altruism: The evolution of empathy. Annu. Rev. Psychol. 2008, 59, 279-300. [CrossRef]

55. Kruse, P.; Wach, D.; Costa, S.; Moriano, J.A. Values Matter, Don't They?-Combining theory of planned behavior and personal values as predictors of social entrepreneurial intention. J. Soc. Entrep. 2018, 10, 55-83. [CrossRef]

56. Bacq, S.; Alt, E. Feeling capable and valued: A prosocial perspective on the link between empathy and social entrepreneurial intentions. J. Bus. Ventur. 2018, 33, 333-350. [CrossRef]

57. Davis, M.H. Empathy and prosocial behavior. In The Oxford Handbook of Prosocial Behavior; Schroeder, D.A., Graziano, W.G., Eds.; Oxford University Press: New York, NY, USA, 2015.

58. De Groot, J.I.M.; Steg, L. Value orientations to explain beliefs related to environmental significant behavior: How to measure egoistic, altruistic, and biospheric value orientations. Environ. Behav. 2008, 40, 330-354. [CrossRef]

59. Singh, S.K.; Singh, A.P. Interplay of organizational justice, psychological empowerment, organizational citizenship behavior, and job satisfaction in the context of circular economy. Manag. Decis. 2019, 57, 937-952. [CrossRef]

60. Anser, M.K.; Yousaf, Z.; Majid, A.; Yasir, M. Does corporate social responsibility commitment and participation predict environmental and social performance? Corp. Social Responsib. Environ. Manag. 2020, 27, 2578-2587. [CrossRef]

61. Shapero, A.; Sokol, L. The social dimensions of entrepreneurship. In the Encyclopedia of Entrepreneurship; Kent, C., Sexton, D., Vesper, K., Eds.; Prentice Hall: Englewood Cliffs, NJ, USA, 1982; pp. 72-90.

62. Mair, J.; Marti, I. Social entrepreneurship research: A source of explanation, prediction, and delight. J. World Bus. 2006, 41, 36-44. [CrossRef]

63. Dietz, T.; Fitzgerald, A.; Shwom, R. Environmental values. Annu. Rev. Environ. Resour. 2005, 30, 335-372. [CrossRef]

64. Cabral, C.; Jabbour, C.J.C. Understanding the human side of green hospitality management. Int. J. Hospit. Manag. $2020,88,102389$. [CrossRef] 
65. Islam, T.; Ali, G.; Asad, H. Environmental CSR and pro-environmental behaviors to reduce environmental dilapidation. Manag. Res. Rev. 2019, 42, 332-351. [CrossRef]

66. Schultz, P.W.; Gouveia, V.V.; Cameron, L.D.; Tankha, G.; Schmuck, P.; Franik, M. Values and their relationship to environmental concern and conservation behavior. J. Cross-Cult. Psychol. 2005, 36, 457-475. [CrossRef]

67. Schenk, P. A matter of principle: Comparing norm-based explanations for fair trade consumption. J. Consum. Policy 2019, 42, 397-423. [CrossRef]

68. Burkhardt, K.; Nguyen, P.; Poincelot, E. Agents of change: Women in top management and corporate environmental performance. Corp. Social Responsib. Environ. Manag. 2020, 27, 1591-1604. [CrossRef]

69. Neneh, B.N. From entrepreneurial alertness to entrepreneurial behavior: The role of trait competitiveness and proactive personality. Pers. Indiv. Differ. 2019, 138, 273-279. [CrossRef]

70. Lindenberg, S.; Steg, L. Normative, gain and hedonic goal-frames guiding environmental behavior. J. Soc. Issues 2007, 63, 117-137. [CrossRef]

71. UNDP. Human Development Report Unleashing the Potential of a Young Pakistan; UNDP Development Policy Unit: Islamabad, Pakistan, 2017; Available online: https:/ / www.pk.undp.org/ (accessed on 12 May 2021).

72. Sher, A.; Adil, S.A.; Mushtaq, K.; Ali, A.; Hussain, M. An investigation of entrepreneurial intentions of agricultural students. Pak. J. Agric. Sci. 2017, 54, 941-945. [CrossRef]

73. Vrontis, D.; Papasolomou, I. Brand and product building: The case of the Cyprus wine industry. J. Prod. Brand Manag. 2007, 16, 159-167. [CrossRef]

74. Dickson, P.H.; Solomon, G.T.; Weaver, K.M. Entrepreneurial selection and success: Does education matter? J. Small Bus. Enterp. Dev. 2008, 15, 239-258. [CrossRef]

75. Popescu, C.; Bostan, I.; Robu, I.B.; Maxim, A. An analysis of the determinants of entrepreneurial intentions among students: A Romanian case study. Sustainability 2016, 8, 771. [CrossRef]

76. Podsakoff, P.M.; MacKenzie, S.B.; Lee, J.-Y.; Podsakoff, N.P. Common method biases in behavioral research: A critical review of the literature and recommended remedies. J. Appl. Psychol. 2003, 88, 879. [CrossRef]

77. O'brien, R.M. A Caution Regarding Rules of Thumb for Variance Inflation Factors. Qual. Quant. 2007, 41, 673-690. [CrossRef]

78. Knudson, W.; Wysocki, A.; Champagne, J.; Peterson, H.C. Entrepreneurship and innovation in the agri-food system. Am. J. Agric. Econ. 2004, 86, 1330-1336. [CrossRef]

79. Wadhwa, V.; Freeman, R.; Rissing, B. Education and tech entrepreneurship. Innov. Technol. Gov. Glob. 2010, 5, 141-153. [CrossRef]

80. Kolvereid, L. Prediction of employment status choice intentions. Enterp. Theor. Pract. 1996, 21, 47-58. [CrossRef]

81. Autio, E.; Keeley, R.H.; Klofsten, M.; Parker, G.C.; Hay, M. Entrepreneurial intent among students in Scandinavia and in the USA. Enterp. Innov. Manag. Stud. 2001, 2, 145-160. [CrossRef]

82. Zapkau, F.B.; Schwens, C.; Steinmetz, H.; Kabst, R. Disentangling the effect of prior entrepreneurial exposure on entrepreneurial intention. J. Bus. Res. 2015, 68, 639-653. [CrossRef]

83. Jaiswal, D.; Kant, R. Green purchasing behaviour: A conceptual framework and empirical investigation of Indian consumers. J. Retail. Consum. Serv. 2018, 41, 60-69. [CrossRef]

84. Tabachnick, B.G.; Fidell, L.S. Using Multivariate Statistics, 4th ed.; Harper-Collins: New York, NY, USA, 2001.

85. Anderson, J.C.; Gerbing, D.W. Structural equation modeling in practice: A review and recommended two-step approach. Psychol. Bull. 1988, 103, 411-423. [CrossRef]

86. Hair, J.F., Jr.; Black, W.C.; Babin, B.J.; Anderson, R.E. Multivariate Data Analysis, 7th ed.; Prentice Hall: Upper Saddle River, NJ, USA, 2009.

87. Kline, R.B. Principles and Practice of Structural Equation Modelling, 2nd ed.; The Guilford: New York, NY, USA, 2005.

88. Fornell, G.; Lacker, R.N. Introduction to Linear Regression Analysis; John Wiley and Sons: New York, NY, USA, 1981.

89. Hair, J.; Anderson, R.; Tatham, R.; Black, W. Análisis Multivariante; Pearson Prentice Hall: Madrid, Spain, 2010.

90. Hu, L.T.; Bentler, P.M. Cutoffcriteria for fit indexes in covariance structure analysis: Conventional criteria versus new alternatives. Struct. Equ. Model. 1999, 6, 1-55. [CrossRef]

91. Bentler, P.M.; Bonett, D.G. Significance tests and goodness of fit in the analysis of covariance structures. Psychol. Bull. 1980, 88, 588. [CrossRef]

92. Hockerts, K. The social entrepreneurial antecedents scale (SEAS): A validation study. Soc. Enterp. J. 2015, 11, 260-280. [CrossRef]

93. Schlaegel, C.; Koenig, M. Determinants of entrepreneurial intent: A meta-analytic test and integration of competing models. Entrep. Theory Pract. 2014, 38, 291-332. [CrossRef]

94. Douglas, E.J.; Shepherd, D.A. Self-employment as a career choice: Attitudes, entrepreneurial intentions, and utility maximization. Enterp. Theor. Pract. 2002, 26, 81-90. [CrossRef]

95. Ru, X.; Qin, H.; Wang, S. Young people's behaviour intentions towards reducing PM2.5 in China: Extending the theory of planned behaviour. Resour. Conserv. Recycl. 2019, 141, 99-108. [CrossRef]

96. Zhao, X.; Lynch, J.G., Jr.; Chen, Q. Reconsidering baron and Kenny: Myths and truths about mediation analysis. J. Consum. Res. 2010, 37, 197-206. [CrossRef]

97. Baron, R.M.; Kenny, D.A. The moderator-mediator variable distinction in social psychological research: Conceptual, strategic and statistical considerations. J. Personal. Soc. Psychol. 1986, 51, 1173-1182. [CrossRef] 
98. Edwards, J.R.; Lisa Schurer, L. Methods for integrating moderation and mediation: A general analytical framework using moderated path analysis. Psychol. Methods 2007, 12,1-22. [CrossRef]

99. Yi, G. From green entrepreneurial intentions to green entrepreneurial behaviors: The role of university entrepreneurial support and external institutional support. Int. Entrep. Manag. J. 2020, 13, 963-979. [CrossRef]

100. Urban, B.; Kujinga, L. The institutional environment and social entrepreneurship intentions. Int. J. Entrep. Behav. Res. 2017, 23, 638-655. [CrossRef]

101. Munoz, P. A cognitive map of sustainable decision-making in entrepreneurship: A configurationally approach. Int. J. Entrep. Behav. Res. 2018, 24, 787-813. [CrossRef]

102. Dickel, P.; Hörisch, J.; Ritter, T. Networking for the environment: The impact of environmental orientation on start-ups' networking frequency and network size. J. Clean. Prod. 2018, 179, 308-316. [CrossRef]

103. Yasir, N.; Liren, A.; Mehmood, N.; Arfat, Y. Impact of personality traits on entrepreneurial intention and demographic factors as moderator. Int. J. Entrep. 2019, 23, 1-20.

104. Short, J.C.; Moss, T.W.; Lumpkin, G.T. Research in social entrepreneurship: Past contributions and future opportunities. Strateg. Entrep. J. 2009, 3, 161-194. [CrossRef]

105. Schwartz, S.H. Universals in the content and structure of values: Theoretical advances and empirical tests in 20 countries. In Advances in Experimental Social Psychology; Zanna, M.P., Ed.; Academic Press: New York, NY, USA, 1992.

106. Singh, S.K.; Pradhan, R.K.; Panigrahy, N.P.; Jena, L.K. Self-efficacy and workplace well-being: Moderating role of sustainability practices. Benchmark Int. J. 2019, 26, 1692-1708. [CrossRef]

107. Andreas, K.; Wagner, M. The influence of sustainability orientation on entrepreneurial intentions-Investigating the role of business experience. J. Bus. Ventur. 2010, 25, 524-539.

108. Liu, M.T.; Liu, Y.; Mo, Z. Moral norm is the key: An extension of the theory of planned behaviour (TPB) on Chinese consumers' green purchase intention. Asia Pac. J. Market. Logist. 2020, 32, 1823-1841. [CrossRef]

109. Lans, T.; Blok, V.; Wesselink, R. Learning apart and together: Towards an integrated competence framework for sustainable entrepreneurship in higher education. J. Clean. Prod. 2014, 62, 37-47. [CrossRef]

110. Ploum, L.; Blok, V.; Lans, T.; Omta, O. Toward a validated competence framework for sustainable entrepreneurship. Organ. Environ. 2018, 31, 113-132. [CrossRef] [PubMed]

111. Yasir, N.; Liren, A.; Mahmood, N.; Mehmood, H.S. The role of personality traits, entrepreneurship education and self-efficacy as mediating effect on the entrepreneurial intention. Dilemas Contemp. Educ. Polit. Valore 2019, 6, 1-26. 